\title{
Italy and Neutrality: Cultural, Political and Diplomatic Framework
}

\author{
Andrea Carteny \\ Sapienza University of Rome \\ Email: andrea.carteny@uniroma1.it
}

Doi:10.5901/mjss.2015.v6n6s2p737

\begin{abstract}
Italian history at the beginning of WWI was well harmonised with other events in the Old Continent, while the domestic picture featured a delicate set of links, between Triplicist, neutralist, and nationalist environments, parties and movements, with "nationalism" acting as a shaping factor in Italy's public scene. But different elements emerged in Italian nationalism that would grow into the interventionist policy of an aspiring "great power", interpreted by some as a line of continuity between liberal and fascist foreign policy. The period of neutrality and the events that led to Italy's intervention were in the spotlight of historiographical analysis in the post-war years, with both focus on fascist Italy's non-belligerance at the surge of WWII and special attention to documentation and the strategies of protagonists (e.g. Giolitti, Salandra, di San Giuliano, Sonnino, D'Annunzio, etc.), as well as to careful reconstruction of events the growing consensus for intervention, the personalisation of stances for and against intervention, the many elements at play within and outside the country and the clever combination of popular mobilisation and parliamentary strategy by supporters of intervention in the weeks between the Treaty of London and war. The goal of the paper is to present the evolution of the Italian position from neutrality to the intervention in the war alongside the Entente, with a particular attention to international context, to the protagonist of the neutrality period in Italy through the memories and the main historiography on the subject.
\end{abstract}

Keywords: Neutrality, Nationalism, Italy, Intervention, Memories,

\section{Introduction}

"The neutrality of late July and early August is more important and significant than the famous Days of May" ("La neutralità di fine luglio e dei primi d'agosto è più importante e significativa delle famose giornate di maggio"), argues one of the most comprehensive volumes on the topic (Vigezzi, 1966: XIII). In fact, the period between Vienna's ultimatum to Serbia (July 23 $\left.{ }^{\text {rd }}, 1914\right)$ and Italy's declaration of war to the Austro-Hungarian Empire (May 23 $\left.{ }^{\text {rd }}, 1915\right)$ was characterised by neutrality on the side of Italy, strongly anchored in its position as the "last of the great powers" (Decleva, 1974; Serra, 1990) in the international context of the time. Italian history was then well harmonised with events in the Old Continent, while the domestic picture featured a delicate set of interconnections between Triplicist, neutralist, and nationalist environments, parties, and movements, with "nationalism" acting as a shaping factor in Italy's public scene. Obviously, such interactions fit into a net of complex international interdependence - where a local crisis could turn into a European and worldwide conflict (Rusconi, 1987), or a country's policy could shift from neutrality to intervention (Rusconi, 2009) which shuffled the cards in the alliance system formed during the age "of empires" and imperialisms (Hobsbawm, 1987). Domestic debate was not limited to the one between supporters of the Triple Alliance in the ruling class and nationalist and interventionist environments, but extended to the in-between position that valued neutrality as the best choice.

In addition to the history of "facts" and the history of "ideas", historiography has addressed these topics through the lenses of a new historical vision, able to highlight the human and material aspects most invested by the conflict (or the expectation of the conflict), but also the dramatic end of the much celebrated belle époque that had announced - perhaps too hastily - peace and progress for humanity (Valeri, 1975). Optimistic outlooks also extended to the political field, where the socialists of the Second International, including in Italy, in front of new improvements in the conditions of working and subaltern classes, would see the conflict as "carnage", a "civil war". Against this backdrop, two more international stances were competing: the aristocratic and legitimist one, a residue - yet a still reactive one - of the ancien régime, and the bourgeois, capitalist one, based on the force of modernity (Isnenghi-Rochat, 2008). Progress, however, also created need for radical change, facilitating the rise of the need for "adventure" that translates into mythicisation of war (Isnenghi, 1970) as well as into the evolution of diplomatic relations, which inevitably reflects the changes in power relationships among European actors, including Giolitti's Italy, starting from the Berlin Congress of 1978 (Albertini, 2010). In such a complex international political framework, united Italy emerges as a rising power and, following the "smack" of Tunisi 
(under French dominion since 1881), seeks in 1911 (time of the Agadir crisis over the French Morocco question, between Germany and France, backed by England) its "fourth shore" with the Lybian campaign (Biagini, 2015; Micheletta-Ungari, 2013) and played an increasingly significant role in the Adriatic and Balkan region in the eve of the Balkan wars in 19121913 (Biagini, 2012).

From a political and military standpoint, during the period of neutrality the Italian government maintained the way of thinking of a country not at war: in times of peace, the army Chief of Staff (the real commander of the armed forces) was subordinated to the Minister of War (an authoritative general), the Prime Minister, and the King, the supreme authority. Italy's neutrality maintained in charge the government of Antonio Salandra, with Domenico Grandi as Minister of War (replaced by General Vittorio Zupelli since October 1914) and Luigi Cadorna as Chief of Staff. However, Salandra's obsession for secrecy, combined with the need to keep several options open, led to a lack of basic communication with Cadorna, who would prepare for war as a last resort for spring 1915 without a dialogue on agreed objectives. Salandra and Cadorna appeared to be moving along "parallel lines" (Isnenghi-Rochat, 2008: 155) that excluded Grandi (engaged in keeping communication lines open between the government and the army leaders) in favour of General Vittorio Zuppelli, who aligned himself with Salandra as his subordinate. As a consequence, the plan for attacking Austria, although consistent with a traditional Resurgence, anti-Austrian approach (Cappellano, 2014), was prepared by Cadorna and only shared with the King, while the Treaty of London was drafted and signed without involving neither the army nor the marine. The fact that the army was finally ready only as late as July, six weeks after the declaration of war, revealed the lack of preparation of the Italian army - the plan drafted the previous year had envisaged complete mobilisation in half of the time. In 1915, the army itself, while improved in artillery organisation, was approximately in the same conditons as in 1914, while the Austro-Hungarian one, though worn out by almost a year of war, appeared stronger than in the beginning of the conflict and able to replace losses (the dead, injured, and sick) and deploy in May 1915 as many soldiers as in August 1914 (about a million and a half).

From a political and ideological standpoint, different elements emerged in Italian nationalism that would grow into the interventionist policy of an aspiring "great power", interpreted by some as a line of continuity between liberal and fascist foreign policy (Bosworth, 1985). The socio-economic and political-cultural basis was taking shape which would stem the controversial genesis of Italian neutrality, with the following, uneasy evolution of Italian policy not only towards intervention, but also towards entering war side by side with the powers of the Entente (Albertini, 1951). Such a radical change in foreign policy was certainly made possible by the accord maintained by united Italy with English and French circles; the bilateral agreements signed in the years preceding the conflict with Paris, London, but also with Petersburg (see the 1909 secret Racconigi Bargain on the Balkans in an anti-Habsburg perspective); the strong ties between the respective national masonries; but mostly by characters able to successfully mediate for the overcoming of geopolitical conflicts, especially with France - in primis, French ambassador in Rome Camille Barrère (Serra, 1950), protagonist with Italian Foreign Minister Giulio Prinetti of the exchange of statements that in 1902 envisaged an agreement on the areas of interest and non-interest in the Mediterranean (Lybia for Italy, Morocco for France) and in favour of mutual neutrality in case of aggression by other powers (Decleva, 1971).

The period of neutrality and the events that led to Italy's intervention were in the spotlight of historiographical analysis in the post-war years, with both focus on fascist Italy's non-belligerance at the surge of WWII (Volpe, 1992) and special attention to documentation (Sonnino, 1974; Sonnino, 1972; Albertini, 1968: Giolitti, 1962) and the strategies of protagonists, including Giolitti, Salandra, di San Giuliano, Sonnino, D’Annunzio, etc. (Vigezzi, 1969; Ferraioli, 2007; Haywood, 1999; Hughes-Hallett, 2014; Guerri, 2008), as well as to careful reconstruction of events (Répaci, 1985; Renzi, 1987). The centenary of Italy entering war inspired recent contributions on the diverse landscape of Italian neutralism (Cammarano, 2015); the growing consensus for intervention (Isnenghi, 2015); the personalisation of stances for and against intervention (Compagna, 2015); the many elements at play within and outside the country (Carioti-Rastelli, 2015); and the clever combination of popular mobilisation and parliamentary strategy by supporters of intervention in the weeks between the Treaty of London and war (Varsori, 2015).

\section{The Choice of Neutrality}

In the days between the assassination of Archduke Franz Ferdinand of Austria and Vienna's ultimatum to Serbia, it was apparent even to Germans (in the words of Foreign Minister Gottlieb von Jagow) that "so far, Italian public opinion has been as Serbophile as it is generally Austro-phobic" ("l'opinione pubblica italiana si è mostrata fin qui tanto serbofila quanto in generale è austrofoba", Albertini, 1951: 43). Neutrality on the side of the Italian government may well have been interpreted as preparation for war, albeit with a peace-time mentality. Support of the Triple Alliance had been the pillar of Italian foreign and military policy since its creation in 1882. Furthermore, with the first renewal in 1887, Austria-Hungary 
had acknowledged Italy's right to fair compensation in case of new gains in the Balkans by the Habsburgs (Salvatorelli, 1939). Most of diplomatic circles (in primis Riccardo Bollati and Giuseppe Avarna, Italian ambassadors respectively in Berlin and in Vienna) were staunch supporters of the Triple Alliance (Varsori, 2015: 67), and so was the army leadership, for example General Alberto Pollio, Chief of Staff, who died on July 1st, 1914. His successor, General Luigi Cadorna, was appointed on July $27^{\text {th }}$ and, before being informed about the different options, was preparing to enact the military convention in an anti-French function (Pieri, 1968: 29-31).

From a formal point of view, since Austria's ultimatum to Serbia was issued without informing Italy as an ally, the obligations of the Alliance were not valid, allowing Foreign Minister Antonino Paternò di San Giuliano to proclaim neutrality (August $2^{\text {nd }}, 1914$ ) and then raise the issue of the compensation stated in art. VII of the text of the Alliance of 1891, renewed in 1912. German support to a preemptive action against Belgrade led to Vienna regarding Italy as it did Romania, which also signed the Alliance, as a minor power (Bosworth, 1985: 422-423), to the point of informing Rome about the ultimatum as late as July $22^{\text {nd }}$, a few hours before issuing it. Lack of information by Vienna, together with lack of compensation for Italy, allowed di San Giuliano (who had already successfully managed Rome's refusal to compensate Vienna in the case of the Italian occupation of Dodecanese, during the Italian-Turkish conflict) not only to declare neutrality, but also - possibly - to leave the Alliance in favour of the Entente (Valiani, 1977: 89-91). Vanished the possibility of a conference of the ambassadors of the great powers to solve the crisis, launched by the Italian Foreign Minister, the conflict would immediately turn from regional - with general mobilisations (July $30^{\text {th }}$ in Russia, $31^{\text {st }}$ in AustriaHungary, August $1^{\text {st }}$ in France) and declarations of war (Germany's against Russia on August $1^{\text {st }}$ and against France on the $3^{\text {rd }}$, Great Britain's against Germany on the $4^{\text {th }}$ ) - into European and then worldwide, with the involvement of colonies and extra-European countries, like Japan and US.

In the spring, Antonio Salandra had succeeded to Giovanni Giolitti as Prime Minister to contain revolutionary leftist forces, but Giolitti's Italy had achieved important results in terms of progress and modernisation (increase of national income from 60 million liras in 1897 to over 90, with the industry sector growing from almost 20\% to 25\%), with industry and finance seeking out new markets in the Balkans and the Mediterranean (Webster, 1974). The population had increased (by almost 4 millions in 15 years, for a total of 36) and become more urbanised and alphabetised, although the South lagged behind and emigration flows had reached 900 thousand units in 1913 (Pelaggi, 2015). In this context, Giovanni Giolitti, directly or indirectly, also thanks to transformist practices, had carried out modernisation and reform policies (Ansaldo, 1963) - for instance, the State no longer backed employers in labour conflicts - extending the government's political and social constituency to radicals (and republicans), socialists, and Catholics. In the early 20th century, the Socialist Party of reformist Filippo Turati had become close to the government area (Arfè, 1965), while Catholic environments had presented new opportunities for collaboration, also thanks to growing engagement at the local level (De Rosa, 1979). Furthermore, with King Vittorio Emanuele III, even the monarchy appeared open to reformist strategies. Economic and social crisis, however, had brought back tensions in the country at the very eve of the conflict. Salandra (who maintained the Ministry of Interiors) had repressed agitations by the socialists who had mobilised in the "red week" of June 1914, and socialists had been beaten in the next administrative elections.

In the first 15 years of the $20^{\text {th }}$ century, nationalism had been emerging in Italy (Gaeta, 1981) with figures of different backgrounds and profiles (including Gabriele D'Annunzio and Enrico Corradini) and growing public activity of magazines and journals, like II Regno, Leonardo, Marzocco (Gaeta, 1965), but also La Voce and Lacerba. Their activities between summer and fall 1914 are among the clearest examples of evolving environments crossing the line between the so-called "liberal party" and interventionist, irredentist nationalism (Vigezzi, 1966: XXXI). Even before the European war, since 1910 and the Turkish-Italian war in 1911, nationalism in Italy shifted from the "cultural" to the "political" dimension (Varsori, 2015: 30). In 1910, the Italian Nationalist Association was created; the following year, The National Idea was published, with contributors including Corradini, Roberto Forges Davanzati, and Francesco Coppola. First an élite, antisocialism, and anti-Giolitti movement, nationalists were able to mobilise the small and middle bourgeoisie, students, and intellectuals, while the futurists of Filippo Tommaso Marinetti created a new vision of art and life with inequivocably bellicist suggestions (Gentile, 2009).

At the eve of the conflict, the Italian Socialist Party itself was torn by bitter internal debate and expulsions: by siding with Giolitti, it gained parliamentary approval for the universal suffrage for men, but in the $13^{\text {th }}$ Congress of July 1912 reformists were put under accusation, and Leonida Bissolati and Ivanoe Bonomi were expelled. The left wing of the party, with Benito Mussolini emerging as a new revolutionary leader against the Lybian war, took the lead, while Mussolini took charge of party newspaper l'Avanti!. In the 1913 elections, social-reformists gained back a fair number of MPs. The party also supported the government on the intervention at the side of the Entente: Leonida Bissolati became a minister in the war governments (June 1916-December 1918) (Colapietra, 1958). The neutralist manifesto of September 21 ${ }^{\text {st }}, 1914$ paved the way for the rift with interventionist revolutionists. On October $18^{\text {th }}$, with the famous article "From absolute 
neutrality to active, operating neutrality" ("Dalla neutralità assoluta alla neutralità attiva ed operante") published on the Avanti!, Benito Mussolini announced his break with socialist neutralism and in November 1914, with the support of Filippo Naldi (former editor of Resto del Carlino) among others, he founded the Popolo d'Italia with explicitly interventionist stances (De Felice, 1965). Although the party's unity was preserved - despite the political distance between reformists and revolutionaries - secretary Costantino Lazzari's claim "neither adhesion nor sabotage" could not avoid the rift with democratic interventionists either (Valiani, 1977).

Catholics were experiencing severe internal conflict about the war too. The churches of Europe, as national bodies, were involved in war mobilisations. The Catholic Church, given its universalist aspirations, suffered the international clash, but Catholics in each country were generally loyal to intervention. In the traditional perspective of alliance between "the throne and the altar", the Catholic Church maintained a strong accord with Austria-Hungary and criticised or opposed the French republican and Italian liberal governments, although with the Gentiloni pact Catholic candidates had run among Giolitti's liberals in the political elections of 1913 (Spadolini, 1974). As regards the European war, however, Giacomo Della Chiesa, elected in September 1914 as Pope Benedetto XV following the death of Pio X, saw the conflict as "God's punishment" over Europe, that had shunned the Church's authority and Christian spirituality: the encyclical $\mathrm{Ad}$ Beatissimi Apostolorum of November 1914 was a fervent call to warring nations to halt the conflict.

In August, the strong impression made by the German advance through Belgium and France, towards Paris, seemed to support the Triplicist thesis. Yet, in mid-September, with the "miracle of Marna" and the stabilisation of the Western front, the stance in favour of the Entente gained ground, also strenghtened by the difficulties met by AustriaHungary in the Serbian campaign (as early as mid-August, with the Serbian victory in the battle of Cer, from the name of the river, also known as battle of Jadar) and on the Eastern front (although the Tsar's troops, after a first advance in Eastern Prussia, were defeated in Tannenberg and on the Masuri lakes) with the Russian advance in Galicia, in Habsburg territory. Over the month, contacts with Romania led to signing a pact, on September 23rd, through which Rome and Bucharest committed to coordinate for neutrality for common goals, claiming those regions under Habsburg dominion inhabited by Italians and Romanians respectively, thus creating the basis for possible entering war simultaneously at the side of the Entente (Biagini, 2007). As early as the first week of August, Russian Foreign Minister Sergey Sazonov had illustrated Italian ambassador Andrea Carlotti the possible gains for Italy - and against Austria - in case of opting for the Entente: di San Giuliano, a staunch Triplicist, suddenly seemed to have become an "Austro-phobe" (Torre, 1963). In fact, he was carefully considering the possible war scenarios, identifying terms of negotiation between intervention with the Entente and neutrality, as Berlin's main objective (Monticone, 1971). On August $9^{\text {th }}$, di San Giuliano first formulated Italy's requests in a letter to Salandra, while a round of contacts with Russian, British, and French representatives increased the Entente's interest and the promised compensation for Italian intervention against Vienna. In these very days, in Fiuggi, where di San Giuliano was recovering from gout, the meetings with German ambassador in Italy Hans von Flotow convinced him that, although Germany could mediate for Austrian compensation to Italy, Vienna was not willing to apply art. VII nor to give up any Habsburg territory (like Trentino). On September $16^{\text {th }}$, having identified London as the most appropriate location for secret contacts with the Entente, di San Giuliano tasked Italian ambassador in the United Kingdom Guglielmo Imperiali with resuming contacts with British Foreign Minister Edward Grey. On September $25^{\text {th }}$, in the famous long telegram to the Cabinet, di San Giuliano finally formulated Italy's requests for the Entente in 16 points, including: naval operations in support to Italy in the Adriatic; militar and naval agreement; in case of victory, the establishment of natural borders - up to the Quarnaro - purposefully leaving out the delicate question of Dalmatia; partition of Albania with Valona under Italian control; preservation of Dodecanese as Italian; Italian control of the Ottoman region of Adalia; war compensation; possible - though unlikely - consideration of compensation in Tunisia for entering war; a loan of at least 40 million pounds on the London stock market. For di San Giuliano and Salandra, the historical moment was favourable for achieving "natural borders" and satisfying "legitimate" national aspirations - Italy's "sacred egoism", as effectively put by Salandra when taking the interim post after the Foreign Minister's death - and needed to be promptly exploited by siding with the Entente, although the complexity of the negotiation and, especially, Italy's notorious lack of military preparation called for slower developments. Despite his premature death on October $16^{\text {th }}$, 1914, di San Giuliano's general terms remained valid during Salandra's interim and Sidney Sonnino's term, until the intervention of the following year (Giordano, 2012: 286-298).

In such a complex framework, the dialectics between interventionist and neutralist parties and movements overlapped with those between popular movements (extreme radical and democratic) and "order" formation (liberal, Catholic, nationalist) without a real match in parties, leaving extensive grey areas on war commitments in the other main split, the one between those "for and against Giolitti" (Vigezzi, 1966: XL). It is therefore appropriate to see, on one side, the neutralism of Catholics and supporters of Giolitti as an expression of sincere fear of democratic interventionism and social revolution; on the other, the interventionism of democratics and nationalists, but also of part of the bourgeoisie, as 
a radical, positive change that Italy needed. The restless personalities in Giolitti's current included more than a few conservative representatives of the liberal party, who resented Giolitti's openings towards socialists and Catholics, that suggested a return to the original spirit of the Risorgimento and the Statuto Albertino, i.e. to the centrality of the monarch. That was the case of Sidney Sonnino, author of the article "Let's go back to the Statute" ("Torniamo allo Statuto"), published in 1897 in journal La Nuova Antologia, former Minister of the Treasury and Finances, Prime Minister (in 1906 and 1909-10), before becoming Foreign Minister in the Salandra II government since November 1914 (Ballini, 2011). The alliance was back with the other influential conservative, Antonio Salandra, with whom Sonnino, in 1901, had founded in Rome I/ Giornale d'Italia, soon to become the main voice of monarchic-conservative liberals against Giolitti. The "national policy" inaugurated by Antonio Salandra, that embodied the need to move away from Giolitti's heritage of the previous 15 years (Carocci, 1971), was the product of such a context.

Sonnino's appointment appeared to be consistent with the previous policy: starting from Triplicist positions, on September $24^{\text {th }}$, Sonnino stated his support for intervention with the Entente. On November $5^{\text {th }}$, once appointed, he prepared to received the long telegram from the government. At the end of the month, ambassador Imperiali, back to Italy for a few days, personally received from Sonnino directions to continue the meetings in London. In the meanwhile, the conflict had spread to the colonial areas in Africa and Asia, while factions had widened: at the end of August, Japan had joined Serbia (and Montenegro) and the Entente and soon fought some German colonies in the Pacific area; the Ottoman empire had sided with Austria-Hungary and Germany between late October and early November. In November, the Austro-Hungarian advance in Serbian territory and the occupation of Belgrade - won back by the Serbs in the first half of December - made the situation more interesting for Italy and Sonnino, who had raised the issue of compensation for the modification of the status quo in the Balkans, calling for Germany's mediation. Contacts in Rome were made with AustroHungarian representative in Italy Karl von Macchio (who had replaced ambassador Kajetan Mérey, prevented from fulfilling his diplomatic function by health issues since the Sarajevo assassination) and especially with Bernhard von Bülow, former German ambassador to Italy, then Foreign Minister and Prime Minister - an authoritative figure in diplomatic mission in Rome. In the meantime Italy, that in the second half of October had already deployed a "sanitary" mission to Valona, had the green light to consolidate a bridgehead in Albanian territory (Montanari, 1978). At the end of December, Italy had occupied the isle of Saseno (strategically important for access to the northern Adriatic) with the marine, and the port of Vlorë with the $10^{\text {th }}$ regiment of Bersaglieri and a mountain battalion.

Sonnino's meetings with von Bülow and then Macchio took place in the first half of December: Berlin confirmed its willingness to maintain good relationships with Italy and mediate to soften Vienna's rigid position (a similar expedition to Vienna followed by prince Karl von Wedel), only characterised at the time by a vague, generic willingness to possibly ceding Trentino and, only following delicate negotiations, greater autonomy for the Italians of Trieste. These points remained mostly unchanged until February, with Vienna making a point of both asking for a "definition" of Trentino and requiring Rome to give up Trieste, while Italy refrained from specifying any request in order not to limit its options and claims. Even Germany's attempt to get the Vatican's mediation for a compromise solution on Trentino (Austria ceding the region to the Vatican, which in turn would give it over to Italy) met both Italy's rejection and the Vatican's skepticism. All over Italy, in the meanwhile, interventionist groups and irredentist associations gained ground, especially thanks to the mobilising skills of figures like Cesare Battisti (Pieri, 1965), former deputy for Trentino in Austria-Hungary and convinced supporter of intervention during Italy's period of neutrality. In the cities, from irredentist and student groups to artistic and intellectual environments, the interventionist minority got better and better organised to push the government towards war. Despite counter-mobilisation by socialists, able to gather large masses in the streets, clashes with interventionists generally turned in favour of the latter (Valiani, 1977: 102).

At the beginning of the year, Italy was hit by another massive earthquake after the one in 1908 . On January $13^{\text {th }}, a$ strong quake hit the area of Marsica, Abruzzo - extending as far as Lazio (the epicentre was in the basin of Fucino, town of Avezzano), killing over 30 thousands. Diplomatic activities - secret and public - were resumed on different fronts in the new year. Dialogue with Romania and Ion Brâtianu started back in January, leading to the secret agreement of February $6^{\text {th }}$, with Rome and Bucharest committing for four months to defend each other if attacked by Vienna. The four-month deadline, set at the eve of the possible intervention, allowed Italy the time and secrecy to negotiate for war. On the nationalist and interventionist fronts, the futurists bashed Italy's "provincial", "petty" nature, its dusty, sterile attachment to the past, calling for war as the "sole hygiene of the world", "medicine" for the evils of the time. Filippo Tommaso Marinetti, Umberto Boccioni, Carlo Carrà, and the futurists organised meetings in theatres and squares to push Italians to war and see a new, modern, "Italianist" nation rise from the blood (Gentile, 2009). Journals like Lacerba filled up with bellicist jubilation with famous Ardengo Soffici and Giovanni Papini. From the heart of warring France, D'Annunzio followed military operations behind the Western front line and relentlessly argued for mobilisation in support of the "Latin brotherhood" on French magazines (like Le Figaro) and on /I Corriere della Sera of his friend and fellow Luigi Albertini. 
His bloody odes and descriptions of French sacrifice waiting for the Italian intervention had great resonance in Italy as well. Italians in Paris, massively present in the world's cultural capital of the time as factory workers, intellectuals, and artists, were mobilising too (Dotoli, 1984). In the early days of national mobilisation, Ricciotto Canudo (musicologist and theorist of film as the ultimate modern "art") and other notable foreign intellectuals called for voluntary enrollment in the French Foreign Legion. Many Italians answered that call since the early weeks of the conflict (Milza, 1986), and wearing the red shirt under the French uniform they formed the legion of Peppino Garibaldi, son of Ricciotti, that would be decimated in the Forest of Argonne (Répaci, 1985).

The neutralist front relied on the only figure able to gather political and civic consensus: Giovanni Giolitti, a neutralist since the early days of conflict, who was convinced that Italy was unprepared for war and concerned about the social risks of intervention. After a series of meetings with journalists, politicians, and diplomats (like the famous one with von Bülow), in the beginning of the year he was prompted by his entourage to take a stand to prevent an interventionist turn. In a letter dated January $20^{\text {th }}$, he defended his neutralist stance, defined war as a "disgrace", and argued that Italy could obtain "a lot" ("molto") without war. Published on La Tribuna on February 1 1', the letter read "quite a lot" ("parecchio") instead of "a lot", with the former phrase becoming the formula of the opportunist neutralism of Giolitti supporters. The press wars had already started in the fall, with significant German investment in Triplicist propaganda and French interventionist activity in support of the Entente, including with strong contacts between Italian and French masons (Mola, 1976).

In February, Berlin tasked German Catholic MP Matthias Erzberger with mediating between the Vatican and the Italian government. However, Sonnino and the liberal government of resurgentist tradition would firmly oppose any involvement of the Vatican. Although the dialogue remained officially open for Austrian compensation to Italy, secret negotiations were resumed in London since March $1^{\text {st }}$, given the virtual stagnation of dialogue with Austria despite the German mediation (Monticone, 1971). On the war front, the Allies led Italy and other neutral countries to believe in an upcoming turn with the operations against the Ottoman Empire, aimed at landing in Gallipoli to reach Constantinople. Since early March, with the king's placet, ambassador Imperiali resumed negotiations with Grey on the basis of the "long telegram". Doubts started to emerge on the demands related to the Adriatic area, in Albania and Dalmatia, especially in pro-Serbian circles, in primis the Russian government, as well as Anatolia. In the same days, Vienna (where in early January Foreign Minister Leopold Berchtold had been replaced by István Burián because of his position, too open to the possibility of ceding Trentino) decided to resume negotiations directly with Rome (Valiani, 1966: 108), as von Bülow communicated to Sonnino on March $8^{\text {th }}$. Pressured by interventionist public opinion, excited by the Allies landing to Gallipoli, the Italian government immediately raised the condition of immediate territorial cession (on the basis of nationalists gaining ground) rather than at the end of the conflict, as suggested by Austria. Germany's mediation seemed to leave some options open, but direct meetings between ambassador Avarna and Burián, taking place in Vienna in late March, showed that Austria was only willing to negotiate on part of Trentino. In early April, however, Vienna circumscribed Trentino to the territories of Trento, Rovereto, Riva, and Tione. Sonnino eventually defined Austria's proposal as unsatisfactory. With negotiations with the Entente reaching an advanced stage, he presented Vienna with counter-demands analogous to those made to London (Varsori, 2015: 90-93). In mid-April, with some concessions by Italy, an agreement was reached on the peninsula of Sabbioncello, paving the way for the draft of the Treaty of London. At the same time, Vienna envisaged possible further concessions in Trentino, though leaving out the other territories claimed by Rome. The secrecy with which Rome was preparing to sign the Treaty of London pushed Salandra and Sonnino to drag out negotiations with Austria, which found an influential back-up in Giovanni Giolitti, who maintained the majority in Parliament, again at the centre of contacts with von Bülow.

\section{The Treaty of London and the Intervention}

A balance was reached, with the end of the so-called "war of Sabbioncello" and Italian demands leaving out Fiume and Ragusa (Dubrovnik), that after the war, according to Sonnino and Imperiali, would grant access to the sea from the Croatian and Serbian inland respectively. This allowed to reach an agreement on a virtually definitive draft, to be signed on April $26^{\text {th }}$, regarded by Rome as "moderate" and able to avoid Slavic hegemony in the Adriatic even in case of Vienna collapsing - an option that Italian diplomacy did not rule out (Varsori, 2015: 89-90, 113-114). The Treaty of London was then the negotiation basis for intervention with the Entente, aimed at guaranteeing Italy the achievement of the "natural borders" and the "necessary security" in the Adriatica area (Toscano, 1934). It included: military agreements (art. 1) between the Entente (England, France, Russia) and Italy; a naval agreement between Italy, England, and France (art. 3) against Austria-Hungary; cession of Trentino and Tirolo up to Brennero, Trieste, Gorizia, Gradisca, and Istria up to the Quarnaro (art. 4); the province of Dalmatia (art. 5) with part of the opposite islands; the neutrality of the peninsula of 
Sabbioncello and the opposite coast, of the coast from Cattaro to Durrës (except for the territories of Montenegro), and the islands not assigned to Italy; the assignation of the territories of the region to Croatia, Serbia, and Montenegro, and of Durrës to the "Muslim" Independent State of Albania; in Albania (art. 6) Italy received the sovereignity on Vlorë and the island of Saseno; in case of actual assegnation of the lands as per art. 4 and art. 5, Italy would not oppose the partition of northern and southern Albanian regions in favour of Montenegro, Serbia, and Greece. The agreement confirmed: full sovereignity on the Dodecanese; the possible Italian dominion over the Turkish region of Adalia; Italy's dominion over Lybia; compensation in proportion to the military effort; and possible "fair" compensation for increasing the Entente's possessions in the African colonies (art. 13). England committed to immediately issue a 50-million-pounds loan on the London stock market (art. 14), while the Entente committed to support Italy's opposition to the Vatican's participation in peace negotiations (art. 15).

In these very days, through direct contacts, Vienna - aided by Berlin - addressed Rome with new concession proposals (including the status of free cities, though under nominal Austrian sovereignity, for Trieste and Fiume), announcing the arrival in Rome of a new mediator in the person of Count Agenor von Gołuchowski. On the other hand, an exchange of wishes between the Italian and English monarchs and the tsar eventually formalised the involvement of Vittorio Emanuele in Italy's new international positioning. Some rumours on the agreement with the Entente started to surface from the Allies' circles in Paris, and Italy's demands in the Adriatic alarmed not only the well-known pro-Yugoslav circles of the Times, but also the Serbian and Russian governments. At the domestic level, pacifist demonstrations had intensified in view of May $1^{\text {st }}$, while in Lybia the Italian army had suffered a heavy defeat in Gasr bu Hàdi on April $28^{\text {th }}$ (Del Boca, 2004). On May 1st, however, the Council of Ministers finally decided to repeal the Triple Alliance in order to pursue an agreement with the Entente, as the treaty had yet to be officially signed. Salandra and Sonnino were mostly

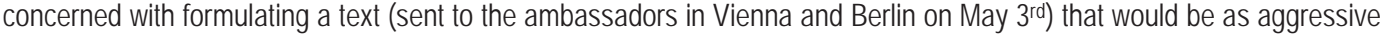
as possible towards Austria and as little aggressive as possible towards Germany. On May $5^{\text {th }}$, von Bülow met Sonnino at Palazzo della Consulta, anticipating Austria's proposal of cession of the entire Trentino, green light on Albania, and autonomy for Trieste with Italian university.

In Italy, in the meantime, various environments mobilised for war. The widening of the interventionist front with the Entente was signalled by the activity of several press organs, in primis /I Corriere della Sera of Luigi Albertini, and the feverish expectation for the glorification of Garibaldi's veterans and Gabriele D'Annunzio, who prepared for a triumphal return. An excellent opportunity came with Garibaldi's veterans invitation to D'Annunzio to join them in Genoa for an interventionist mobilisation with 2 thousands red shirts. Ettore Cozzani, editor of magazine L'Eroica, organised the inauguration of a monument to Garibaldi's Thousand, to be held in Quarto on May $5^{\text {th }}$. Sending the preliminary text to Prime Minister Salandra produced a first round of censorship and led the King to announce he would not attend, contrary to what d'Annunzio had wished. The occasion was favourable for a walkabout: the arrival in Italy on a night train, with the red shirts led by Peppino Garibaldi, was accompanied by crowds cheering for Italy and France. The same happened at the train station in Genoa, where the occasion had gathered noted interventionist figures, including Cesare Battisti (Guerri, 2008: 194). The speech of Quarto, published on May $5^{\text {th }}$ on Corriere della Sera, was riveting, classic D'Annunzio repertoire, evocative of the ancient glories of Roman history and the recent Italian Resurgence. D'Annunzio's speech marked the beginning of the "radiant days of May", with Italian interventionist public opinion bursting into the national political scene and paving the way for an institutional coup (Varsori, 2015).

On the other hand, neutralists gathered around Giolitti. In those days, many sent him alarmed letters about the government's "disinterest" for Austria's proposals and the rumours coming from the Entente's circles about an agreement for intervention against Austria-Hungary. The events of early May (the repeal of the Triple Alliance, the speech of Quarto) convinced him to reach the capital in view of the summoning of the Parliament. On May $6^{\text {th }}$, Austria reiterated the proposals for Italy to stay neutral, both to Rome - directly and indirectly through Vatican contacts - and through German mediation in Berlin. The following day, however, Sonnino announced the Council of Ministers that the Triple Alliance had been repealed and an agreement had been reached with the Entente and communicated to Vienna and Berlin (so that Austria's proposals would appear as non acceptable). On Sunday, May $9^{\text {th }}$, Giolitti reached Rome, while Salandra was being received by Vittorio Emanuele, who encouraged the Prime Minister to meet with Giolitti and stated his willingness to abdicate in case the stability of the monarchy was endangered. After Treasury Minister Paolo Carcano met Giolitti and received his gloomy forecasts in case of war, Salandra returned to the King and declared his willingness to resign. The day after, on Monday morning, the King finally met Giolitti, who indicated backing down from the commitment to the Entente and accepting Vienna's proposals as the best path. When the King shared this with Salandra, he was expectably unwilling to go that way. On the same day, Giolitti finally met Salandra, confirming his position, but reassuring him about his unavailability to lead a new government supporting the Triple Alliance. Giolitti emerged from these meetings as the ultimate arbiter of the situation and received the cards of over 300 MPs in sign of support. On May $11^{\text {th }}$, Sonnino received 
a letter from von Bülow with Austria's last and most favourable proposal to Italy, with Germany's guarantee. Salandra met again with the King for updates on his meeting with Giolitti. On May $12^{\text {th }}$, the Council of Ministers was notified of Austria's latest proposals and the result of the meetings with Giolitti: the government's resignations appeared as the only way out. On May $13^{\text {th }}$, Salandra, in front of a slight parliamentary majority, decided to announce the resignations the day after. The news, already distributed by the Stefani agency in the evening, not only disoriented the Entente's diplomatic circles (present in Rome with French ambassador Barrère, English James Rennel Rodd, and the new Russian ambassador Mikhail Nikolajevic Giers), but gave interventionists the confirmation of the necessity of a mobilisation already ongoing, in front of the possibility of a crisis directed by Giolitti, or rather the success of the so-called "Bülow-Giolitti intrigue" (Varsori, 2015: 159). On May 12th . D'Annunzio's arrival in Rome marked the nationalists' escalation of violence against the neutralists, with about 100 thousand people welcoming and accompanying him to the Hotel Regina. The speech of the following day, Al popolo di Roma in tumulto ("To the people of Rome in turmoil"), was a call for violence, answered by students that tried to assault Montecitorio and Giolitti's residence. While interventionist and nationalist organs like Idea nazionale menacingly appealed to the King in favour of war and Salandra's re-appointment, on the $15^{\text {th }}$ the King met Giolitti to ask for his availability to lead a new government. His refusal of a solution that would exhacerbate tensions, together with lack of alternatives, led Vittorio Emanuele to reject Salandra's resignations on the evening of Sunday, May $16^{\text {th }}$. Interventionists and nationalists rejoiced in Rome (where students were particularly numerous) and Milan (where revolutionary unionists had mobilised, including Mussolini, Corridoni, and Alceste De Ambris). Neutralists, who had produced a few important demonstrations in the previous days (promptly repressed by law enforcement), but unable to mobilise the masses, were by then marginalised. The "radiant days of May" escalated in a rapid succession of events: Salandra, strenghtened by the maneuvre, summoned the Council of Ministers and confirmed the session for May $20^{\text {th }}$ to require full powers in view of the declaration of war. On the $18^{\text {th }}$, while ambassador Macchio, with a glimmer of hope, delivered to Sonnino a proposal for an agreement with Austria, Giolitti left Rome, seeing it as pointless to participate in the parliamentary session. On the $20^{\text {th }}$, Sonnino presented with the Libro Verde ("Green Book") a reconstruction of the failed agreement with Vienna to justify the support to the Entente. With only 64 votes against, Italy prepared to enter war. On May $23^{\text {rd }}$, the declaration of war was delivered to Austria-Hungary. On May $24^{\text {th }}$, the war started on the Eastern border.

\section{Conclusions}

The events that led Italy to abandon neutrality and enter war with the Entente have been elaborated through the historical and popular memories (Mondini, 2014) as well as those of the protagonists (Giolitti, 1972; Salandra, 1928 and 1930) and with focus on results and consequences on liberal Italy (Seton-Watson, 1976), especially on the "beginning of revolution" or "general rehearsal" that the "radiant May" represented for the rise of fascism and the March on Rome (Volpe, 1992; Tasca, 1965) as a virtual coup. In the early post-war period, doubts were already raised on the one hand, about the actual existence of a neutralist majority in the country and its institutions (Croce, 2004); on the other hand, on the diplomatic activity of the Salandra government (Salvemini, 1970). In general, however, historians have confirmed the legitimacy of the choice by democratic interventionists and of the institutional mechanism that led to a parliamentary majority in support of war (Bonomi, 1966).

Anyhow, it is apparent how the organised minority that led Italy into war had its main figures in Salandra and Sonnino, and could count on an agitator like D'Annunzio to mobilise the masses in support of the act of force (Varsori, 2015: 183). The "radiant May" definitely closes Giolitti's age and brings into play new political and civic forces, that would be at the centre of Italy's political life until the end of the Second World War.

\section{References}

Paolo Alatri, 1983: D’Annunzio, Utet, Torino

Luigi Albertini, 2010: Alle origini della guerra del 1914, 3 voll. (I. Le relazioni europee dal Congresso di Berlino all'attentato di Sarajevo, II. La crisi del luglio 1914. Dall'attentato di Sarajevo alla mobilitazione generale dell'Austria-Ungheria, III. L'epilogo della crisi del Iuglio 1914. Le dichiarazioni di guerra e di neutralità), Libreria Editrice Goriziana, Gorizia (original edition: Bocca, Milano $1942-$ 1943)

Luigi Albertini, 1968: Epistolario 1911-1926, I: "Dalla guerra di Libia alla grande guerra", ed. by O. Barié, Mondadori, Milano

Luigi Albertini, 1951: La crisi del luglio '14, la neutralità e l'intervento, Zanichelli editore, Bologna

Giovanni Ansaldo, 1963: II ministro della buona vita. Giolitti e i suoi tempi, Longanesi, Milano

Gaetano Arfè, 1965: Storia del socialismo italiano (1892-1926), Einaudi, Torino

Pier Luigi Ballini (ed), 2011: Sonnino e il suo tempo (1914-1922), Rubbettino, Soveria Mannelli 
Antonello Biagini (ed), 2015: Libia 1911-2015. Dalla Quarta sponda alla minaccia del Califfato, Miraggi, Torino

Antonello Biagini, 2012: L'Italia e le guerre balcaniche, Nuova Cultura, Roma

Antonello Biagini, 2007: Storia della Romania contemporanea, Bompiani, Milano

Ivanoe Bonomi, 1966: La politica italiana da Porta Pia a Vittorio Veneto. 1870-1918, Einaudi, Torino

R.J.B. Bosworth, 1985: La politica estera dell'Italia giolittiana, Editori riuniti, Roma (original edition: Italy, the Least of the Great Powers. Italian Foreign Policy before the First World War, Cambridge University Press, New York 1979)

Fulvio Cammarano, 2015: Abbasso la guerra, Le Monnier, Firenze

Giampiero Carocci, 1971: Giolitti e l'età giolittiana, Einaudi, Torino

Filippo Cappellano, 2014: Piani di guerra dello Stato Maggiore Italiano contro l'Austria-Ungheria (1861-1915), Gino Rossato editore, Vicenza

Antonio Carioti, Paolo Rastelli (eds), 2015: 24 maggio 1915. L'Italia è in guerra, contributi di autori vari, Corriere della Sera, Milano

Piero Chiara, 1981: Vita di Gabriele d'Annunzio, Mondadori, Milano

Raffaele Colapietra, 1958: Leonida Bissolati, Feltrinelli, Milano

Luigi Compagna, 2015: Italia 1915: in guerra contro Giolitti, Rubbettino, Soveria Mannelli

Benedetto Croce, 2004: Storia d'Italia dal 1871 al 1915, Adelphi, Milano (forst edition: Laterza, Bari 1928)

Enrico Decleva, 1974: L'Italia e la politica internazionale dal 1870 al 1914. L'ultima fra le grandi potenze, Mursia, Milano

Enrico Decleva, 1971: Da Adua a Sarajevo. La politica estera italiana e la Francia, 1896-1914, Laterza, Bari

Renzo De Felice, 1965: Mussolini il rivoluzionario (1883-1920), Einaudi, Torino

Angelo Del Boca, 2004: La disfatta di Gasr Bu Hàdi. 1915: il colonnello Miani e il più grande disastro dell'Italia coloniale, Mondadori, Milano

Gabriele De Rosa, 1979: II movimento cattolico in Italia. Dalla Restaurazione all'età giolittiana, Laterza, Roma-Bari

Giovanni Dotoli, 1984: Paris ville visage du monde chez Ricciotto Canudo et l'avant garde italienne, Schena, Fasano

Gian Paolo Ferraioli, 2007: Politica e diplomazia in Italia tra XIX e XX secolo. Vita di Antonino di San Giuliano (1871-1914), Rubbettino, Soveria Mannelli

Franco Gaeta, 1981: II nazionalismo italiano, Laterza, Roma-Bari

Franco Gaeta, 1965: La stampa nazionalista, a cura di, Cappelli, Bologna

Emilio Gentile, 2009: La nostra sfida alle stelle: futuristi in politica, Laterza, Roma-Bari 2009

Giovanni Giolitti, 1972: Le memorie della mia vita, Treves, Milano

Giovanni Giolitti, 1962: Dai prodromi della grande guerra al fascismo, 1910-1928, a cura di C. Pavone, Feltrinelli, Milano

Giordano Giancarlo, 2012: Tra marsine e stiffelius: venticinque anni di politica estera italiana, 1900-1925, Nuova Cultura, Roma

Geoffrey A. Haywood, 1999: Failure of a Dream. Sidney Sonnino and the Rise and Fall of Liberal Italy: 1847-1922, Olschki, Firenze

Giordano Bruno Guerri, 2008: D'Annunzio: l'amante guerriero, Mondadori, Milano

Eric J. Hobsbawm, 1987: L'età degli imperi, 1875-1914, Laterza, Roma-Bari

Lucy Hughes-Hallett, 2014: Gabriele d'Annunzio: l'uomo, il poeta, il sogno di una vita come opera d'arte, Rizzoli, Milano (original edition:

The Pike. Gabriele d'Annunzio Poet, Seducer and Preacher of War, Fourth Estate, London 2013)

Mario Isnenghi, Giorgio Rochat, 2008: La Grande Guerra, 1914-1918, II Mulino, Bologna

Mario Isnenghi, 2015: Convertirsi alla guerra: liquidazioni, mobilitazioni e abiure nell'Italia tra il 1914 e il 1918, Donzelli, Roma

Mario Isnenghi, 1970: II mito della grande guerra da Marinetti a Malaparte, Laterza, Roma-Bari

Federico Lucarini, 2012: La carriera di un gentiluomo. Antonio Salandra e la ricerca di un liberalismo nazionale (1875-1922), II Mulino, Bologna

Luca Micheletta, Andrea Ungari (eds), 2013: L'Italia e la guerra di Libia cent'anni dopo, Studium, Roma

Pierre Milza (ed.), 1986: Les Italiens en France de 1914 à 1940, École française de Rome, Roma

Aldo Mola, 1976: Storia della Massoneria italiana dall'Unità alla Repubblica, Bompiani, Milano

Marco Mondini, 2014: La guerra italiana. Partire, raccontare, tornare, 1914-18, II Mulino, Bologna

Mario Montanari, 1978: Le truppe italiane in Albania (anni 1914-1920 e 1939), Ufficio Storico SME, Roma

Alberto Monticone, 1971: La Germania e la neutralità italiana, II Mulino, Bologna

Stefano Pelaggi, 2015: /l colonialismo popolare. L'emigrazione e la tentazione espansionistica italiana in America latina, Nuova Cultura, Roma

Piero Pieri, 1968: L'Italia nella prima guerra mondiale (1915-1918), Einaudi, Torino

Piero Pieri, 1965: Cesare Battisti nella storia d'Italia, Tipografia Editrice Temi, Trento

Antonino Répaci, 1985: Da Sarajevo al "maggio radioso". L'Italia verso la prima guerra mondiale, Mursia, Milano

William A. Renzi, 1987: In the Shadow of the Sword. Italy's Neutrality and Entrance into the Great War, 1914-1915, Peter Lang, New York

Gian Enrico Rusconi, 2009: L'azzardo del 1915. Come I'Italia decide la sua guerra, II Mulino, Bologna

Gian Enrico Rusconi, 1987: Rischio 1914. Come si decide una guerra, II Mulino, Bologna

Giambattista Gifuni(a cura di), 1969: Il diario di Salandra, Pan editore, Milano

Antonio Salandra, 1930: L'intervento. Ricordi e pensieri, Mondadori, Milano

Antonio Salandra, 1928: La neutralità italiana, 1914. Ricordi e pensieri, Mondadori, Milano

Luigi Salvatorelli, 1939: La Triplice alleanza. Storia diplomatica, 1877-1912, Ispi, Milano

Gaetano Salvemini, 1970: Opere, voll. III (“Scritti di politica estera"), IV (“La politica estera italiana dal 1871 al 1915"), Feltrinelli, Milano 
Enrico Serra, 1990: L'Italia e le grandi alleanze nel tempo dell'imperialismo. Saggio di tecnica diplomatica, 1870-1915, Franco Angeli, Milano

Enrico Serra, 1950: Camille Barrère e l'intesa italo-francese, Giuffrè, Milano

Christopher Seton-Watson, 1976: L'Italia dal liberalismo al fascismo, 1870-1925, 2 voll., Laterza, Roma-Bari (original edition: Italy from liberalism to fascism: 1870-1925, Methuen \& Co., London 1967)

Sidney Sonnino, 1974: Carteggio 1914-1916, ed. by P. Pastorelli, Laterza, Bari

Sidney Sonnino, 1972: Diario, Il: 1914-1916, ed. by di P. Pastorelli, Laterza, Bari 1972

Giovanni Spadolini, 1974: Giolitti e i cattolici (1901-1914), Le Monnier, Firenze

Angelo Tasca, 1965: Nascita e avvento del fascismo. L'Italia dal 1918 al 1922, Laterza, Roma-Bari (prima edizione italiana: La Nuova Italia, Firenze 1950)

Andrea Torre, 1963: Il primo conflitto mondiale (1914-1918). La neutralità e l'intervento. La guerra e la vittoria, in: AA.VV., La politica estera italiana dal 1914 al 1943, ERI, Torino

Mario Toscano, 1934: Il Patto di Londra, Zanichelli, Bologna

Nino Valeri, 1975: Dalla "belle époque" al fascismo. Momenti e personaggi, Roma-Bari, Laterza,

Leo Valiani, 1977: II Partito socialista italiano nel periodo della neutralità: 1914-1915, Feltrinelli, Milano

Leo Valiani, 1966: La dissoluzione dell'Austria-Ungheria, Milano, II Saggiatore

Antonio Varsori, 2015: Radioso maggio. Come l'Italia entrò in guerra, II Mulino, Bologna

Bruno Vigezzi, 1969: Da Giolitti a Salandra, Vallecchi, Firenze

Brunello Vigezzi, 1966: L'Italia di fronte alla Prima Guerra Mondiale, Vol. I: L'Italia neutrale, Riccardo Ricciardi editore, Milano-Napoli

Gioacchino Volpe, 1992: II popolo italiano tra la pace e la guerra, 1914-1915, Bonacci, Roma (original edition: Istituto per gli Studi di Politica Internazionale, Milano 1940)

Richard A. Webster, 1974: L'imperialismo industriale italiano, 1908-1915. Studio sul prefascismo, Einaudi, Torino 